\title{
Energy Inhibition Elevates $\beta$-Secretase Levels and Activity and Is Potentially Amyloidogenic in APP Transgenic Mice: Possible Early Events in Alzheimer's Disease Pathogenesis
}

\author{
Rodney A. Velliquette, ${ }^{1,2}$ Tracy 0 'Connor, ${ }^{1}$ and Robert Vassar ${ }^{1,2}$ \\ ${ }^{1}$ Department of Cell and Molecular Biology and ${ }^{2}$ Center for Drug Discovery and Chemical Biology, Northwestern University, The Feinberg School of \\ Medicine, Chicago, Illinois 60611
}

\begin{abstract}
$\beta$-Secretase [ $\beta$-site amyloid precursor protein-cleaving enzyme 1 (BACE1)] is the key rate-limiting enzyme for the production of the $\beta$-amyloid $(\mathrm{A} \beta$ ) peptide involved in the pathogenesis of Alzheimer's disease (AD). BACE1 levels and activity are increased in AD brain and are likely to drive $A \beta$ overproduction, but the cause of $B A C E 1$ elevation in $A D$ is unknown. Interestingly, cerebral glucose metabolism and blood flow are both reduced in preclinical $\mathrm{AD}$, suggesting that impaired energy production may be an early pathologic event in $\mathrm{AD}$. To determine whether reduced energy metabolism would cause BACE1 elevation, we used pharmacological agents (insulin, 2-deoxyglucose, 3-nitropropionic acid, and kainic acid) to induce acute energy inhibition in C57/B6 wild-type and amyloid precursor protein (APP) transgenic (Tg2576) mice. Four hours after treatment, we observed that reduced energy production caused a $\sim 150 \%$ increase of cerebral BACE1 levels compared with control. Although this was a modest increase, the effect was long-lasting, because levels of the BACE1 enzyme remained elevated for at least $7 \mathrm{~d}$ after a single dose of energy inhibitor. In Tg2576 mice, levels of the BACE1-cleaved APP ectodomain APPs $\beta$ were also elevated and paralleled the BACE1 increase in both relative amount and duration. Importantly, cerebral A $\beta 40$ levels in Tg2576 were increased to $\sim 200 \%$ of control at $7 \mathrm{~d}$ after injection, demonstrating that energy inhibition was potentially amyloidogenic. These results support the hypothesis that impaired energy production in the brain may drive AD pathogenesis by elevating BACE1 levels and activity, which, in turn, lead to $\mathrm{A} \beta$ overproduction. This process may represent one of the earliest pathogenic events in AD.
\end{abstract}

Key words: Alzheimer's disease pathogenesis; $\beta$-secretase; BACE1; $\beta$-amyloid peptide; APP transgenic mice; energy metabolism

\section{Introduction}

Alzheimer's disease $(\mathrm{AD})$ is characterized by senile plaques composed of $\beta$-amyloid $(\mathrm{A} \beta$ ) peptide (Glenner and Wong, 1984; Masters et al., 1985). The 42 aa $\mathrm{A} \beta(\mathrm{A} \beta 42)$ may induce $\mathrm{AD}$ pathogenesis, because early-onset familial AD (FAD) mutations increase A $\beta 42$ production (Younkin, 1998; Hardy and Selkoe, 2002). Although the molecular pathophysiology in sporadic cases of $\mathrm{AD}(\mathrm{SAD})$ is unknown, it is likely to also involve $\mathrm{A} \beta 42$.

$\mathrm{A} \beta$ is cleaved from the amyloid precursor protein (APP) by two enzymes, the $\beta$ - and $\gamma$-secretases (Sisodia et al., 1999; Esler and Wolfe, 2001). First, APP is cut by $\beta$-secretase to produce the secreted $\operatorname{APPs} \beta$ ectodomain and the membrane-bound C-terminal fragment C99. Next, C99 is cleaved by $\gamma$-secretase,

\footnotetext{
Received June 8, 2005; revised Aug. 23, 2005; accepted 0ct. 7, 2005.

This work was supported by Northwestern University start-up funds (to R.V.). R.A.V. is a postdoctoral fellow and is supported by a training grant from the Center for Drug Discovery and the Chemical Biology Training Grant; T.0. is a graduate student in the Northwestern University Integrated Graduate Program and is supported by the Mechanisms of Aging and Dementia Training Grant. We thank Holly Oakley and Erika Maus for mouse colony maintenance and the Vassar laboratory for helpful advice and discussions. BACE1 ${ }^{-1-}$ mice used as negative controls were a gift from Amgen (Thousand Oaks, CA).

Correspondence should be addressed to Dr. Robert Vassar, Department of Cell and Molecular Biology, Northwestern University, The Feinberg School of Medicine, 303 East Chicago Avenue, Chicago, IL 60611. E-mail: r-vassar@northwestern.edu.

DOI:10.1523/JNEUROSCI.2350-05.2005

Copyright $\odot 2005$ Society for Neuroscience $\quad$ 0270-6474/05/2510874-10\$15.00/0
}

which releases $\mathrm{A} \beta$. The $\beta$-secretase, $\beta$-site amyloid precursor protein-cleaving enzyme 1 (BACE1), is the key rate-limiting enzyme for the generation of $\mathrm{A} \beta$ (Hussain et al., 1999; Sinha et al., 1999; Vassar et al., 1999; Yan et al., 1999; Lin et al., 2000). FAD cases caused by the APP Swedish mutation (K670N, M671L) (Mullan et al., 1992), which enhances cleavage by BACE1 (Citron et al., 1992), imply that increased activity of BACE1 may be sufficient to induce $\mathrm{AD}$ pathogenesis. Interestingly, levels of BACE1 protein and activity are elevated in SAD brains (Fukumoto et al., 2002; Holsinger et al., 2002; Tyler et al., 2002; Yang et al., 2003; Li et al., 2004), suggesting that high BACE1 activity may drive $\mathrm{A} \beta$ overproduction and thus promote AD. However, the underlying physiological mechanism responsible for BACE1 elevation in SAD is unknown.

In the search for mechanisms that increase BACE1 levels in SAD, impaired energy production emerged as a likely candidate. Positron emission tomography imaging studies have shown that glucose utilization is lower in $\mathrm{AD}$ brains than in age-matched controls (de Leon et al., 1983a,b; Rapoport et al., 1991; Rapoport, 1999). Furthermore, reduced brain glucose metabolism has also been reported in patients with mild cognitive impairment, suggesting that insufficient energy production may be a factor in preclinical AD (Reiman et al., 1996; Small et al., 2000; De Santis et al., 2001; Mosconi et al., 2004; Mosconi, 2005). In addition, en- 
ergy metabolism inhibition increases amyloidogenic APP processing in vitro (Gabuzda et al., 1994; Gasparini et al., 1997, 1999; Webster et al., 1998).

Although the functions of BACE1 and APP are unclear, both have been implicated in stress/injury response. Importantly, BACE1 levels are elevated after traumatic brain injury (TBI) (Blasko et al., 2004), ischemia (Wen et al., 2004), and oxidative stress (Tamagno et al., 2002; Tong et al., 2005). These observations suggest that stress caused by energy insufficiency may stimulate BACE 1 and $\mathrm{A} \beta$ production, thus triggering SAD. To test this hypothesis, we examined the effects of energy production inhibition on BACE1 levels and APP processing in mouse brain. We found that acute energy inhibition with pharmacological agents in wild-type and APP transgenic mice increased cerebral levels of BACE1, APPs $\beta$, and A $\beta 40$. These results suggest that impaired brain energy metabolism may be one of the earliest proamyloidogenic events in the pathogenesis of SAD.

\section{Materials and Methods}

Animals and drug treatments. C57/B6 and Tg2576 mice were purchased from Taconic Farms (Germantown, NY). The APPSWE (Tg2576) mouse model (Hsiao et al., 1996) carries a transgene coding for the 695 aa isoform of human APP with the Swedish mutation (K670N, M671L; 770 aa isoform numbering) (Mullan et al., 1992). All animals were 2-3 months of age at the time of treatments and were randomized by age, weight, and gender into five experimental groups ( $n=4-9$ animals per group per time) with three recovery times ( $4 \mathrm{~h}, 2 \mathrm{~d}$, and $7 \mathrm{~d}$ ): vehicle ( $0.9 \%$ isotonic saline), insulin (18 U/kg), 2-deoxyglucose (2DG) $(1 \mathrm{~g} / \mathrm{kg})$, 3-nitropropionic acid (3NP) (100 mg/kg), and kainic acid (KA) (30 mg/ $\mathrm{kg}$ ). All agents were administered by a single intraperitoneal injection. Regular insulin was purchased from Henry Schein (Melville, NY), and 2-deoxyglucose, 3-nitropropionic acid, and kainic acid were obtained from Sigma (St. Louis, MO). These procedures were performed with approval from the Northwestern University Animal Use and Care Committee.

Tissue preparation. At $4 \mathrm{~h}, 2 \mathrm{~d}$, or $7 \mathrm{~d}$ after injection, animals were anesthetized with an intraperitoneal injection of pentobarbital $(100 \mathrm{mg} /$ $\mathrm{kg}$ ). When respiration was stable and the mouse no longer responded to foot pinch, skin was rinsed with $70 \%$ ethanol, and an incision was made exposing the heart for transcardial perfusion with $20 \mathrm{ml}$ of cold perfusion buffer: (in mM 10 HEPES, $137 \mathrm{NaCl}, 4.6 \mathrm{KCl}, 1.1 \mathrm{KH}_{2} \mathrm{PO}_{4}, 0.6 \mathrm{MgSO}_{4}$, and 1.1 EDTA) containing protease inhibitors $(20 \mu \mathrm{g} / \mathrm{ml}$ PMSF, 0.5 $\mu \mathrm{g} / \mathrm{ml}$ leupeptin, $20 \mu \mathrm{M}$ sodium orthovanadate, and $100 \mu \mathrm{M}$ DTT). After perfusion, brains were harvested and divided down the midline. Left hemibrains were placed in $4 \%$ paraformaldehyde overnight at $4^{\circ} \mathrm{C}$ for histology, and right hemibrains were snap frozen in liquid $\mathrm{N}_{2}$ for biochemical analyses. Left hemibrains were stored in cryopreserve $[20 \%$ sucrose $(\mathrm{w} / \mathrm{v}), 0.01 \% \mathrm{Na}$-azide $(\mathrm{w} / \mathrm{v}), 0.23 \mathrm{M} \mathrm{NaH}_{2} \mathrm{PO}_{4}$, and $0.2 \mathrm{M}$ $\left.\mathrm{Na}_{2} \mathrm{HPO}_{4}\right]$ at $4^{\circ} \mathrm{C}$, and right hemibrains were stored at $-80^{\circ} \mathrm{C}$ until analysis.

Hemibrains were homogenized in cold PBS containing protease inhibitors, centrifuged at $2000 \times \mathrm{g}$ for $10 \mathrm{~min}$ at $4^{\circ} \mathrm{C}$, supernatant was removed, and total protein concentration was determined by the BCA method (Pierce, Rockford, IL).

Immunoblotanalysis. Hemibrain homogenates $(3 \mathrm{mg} / \mathrm{ml})$ were diluted 1:1 with sample boiling buffer ( $60 \mathrm{~mm}$ Tris, $10 \%$ glycerol, $5 \%$ SDS), $\mathrm{pH}$ 6.8 , and $3.5 \%$ loading dye, and boiled for $5 \mathrm{~min}$. Protein $(15 \mu \mathrm{g})$ was run on 10\% SDS-PAGE (Criterion Gel System; Bio-Rad, Hercules, CA) and transferred onto polyvinylidene difluoride (PVDF) membranes $(0.45$ $\mu \mathrm{m}$ pore; Millipore, Bedford, MA). Membranes were blocked at room temperature for $1 \mathrm{~h}$ in $5 \%$ nonfat milk in Tris-buffered saline containing $0.1 \%$ Tween 20 (TBST) and were then incubated with primary antibody against BACE1 (PA1-757; 1:1000 dilution; Affinity BioReagents, Golden, CO), APP (22C11; 1:5000 dilution; Chemicon, Temecula, CA), APPs $\beta($ sw) neoepitope (1:5000 dilution) (Seubert et al., 1993; Vassar et al., 1999; Cole et al., 2005), or $\beta$-actin (1:15000 dilution; Sigma) at $4^{\circ} \mathrm{C}$ overnight. Subsequently, horseradish peroxidase-conjugated secondary antibodies (Jackson ImmunoResearch, West Grove, PA) were applied to blots for $1 \mathrm{~h}$ at room temperature and detected using enhanced chemiluminescence (ECL+; Amersham Biosciences, Piscataway, NJ). Immunoblot signals for specific proteins were then visualized and measured using an Eastman Kodak (Rochester, NY) CF440 imager and normalized against the $\beta$-actin signal in the same sample for relative quantification. When necessary, blots were stripped (100 mM 2-mercaptoethanol, 2\% SDS, and $62.5 \mathrm{~mm}$ Tris- $\mathrm{HCl}, \mathrm{pH}$ 7.6) for $30 \mathrm{~min}$ at $65^{\circ} \mathrm{C}$ and were then washed in TBST before reincubation with fresh primary antibody.

A $\beta 40$ ELISA. $\mathrm{A} \beta 40$ levels in hemibrain homogenates were determined using an $A \beta 40$-specific sandwich ELISA (BioSource International, Camarillo, CA) according to the recommendations of the manufacturer. Briefly, hemibrains were homogenized in 4 vol of PBS, $500 \mu \mathrm{M} 4-(2-$ aminoethyl)benzenesulfonylfluoride (AEBSF; Calbiochem, La Jolla, $\mathrm{CA}$ ), and total protein concentrations were determined using BCA assay (Pierce, Rockford, IL). Triton X-100 was added to a final concentration of $1 \%$, and samples were sonicated for $\sim 20 \mathrm{~s}$ and adjusted to the same protein concentration $(0.45$ or $0.7 \mu \mathrm{g} / \mu \mathrm{l})$ and then diluted $4.3 \times$ with ELISA kit diluent buffer plus $500 \mu \mathrm{M}$ AEBSF. Equal protein amounts of each sample ( 22.5 or $35 \mu \mathrm{g} /$ well) and A $\beta 40$ standards (diluted in the same ELISA buffer; $500 \mu \mathrm{M}$ AEBSF) were added to ELISA plate wells in duplicate and were then processed for colorimetric development according to the protocol of the manufacturer. Optical densities at $450 \mathrm{~nm}$ of each well were read on a Victor 1420 plate reader (PerkinElmer Life and Analytical Sciences, Turku, Finland), and sample A $\beta 40$ concentrations were determined by comparison with the $\mathrm{A} \beta 40$ standard curve. All readings were in the linear range of the assay. Finally, sample A $\beta 40$ concentration values were normalized to total brain protein concentrations and expressed in picograms per milligram of protein. The average of the duplicates was determined, and then the mean and SEM for a given treatment was calculated.

RNA isolation and real-time PCR. Hemibrains from C57/B6 mice were homogenized in QIAzol Lysis Reagent and RNA was isolated using the RNeasy Lipid Mini kit (Qiagen, Valencia, CA). After RNA concentration determination, $1 \mu \mathrm{g}$ of total RNA from each sample was used for firststrand cDNA synthesis using the Advantage RT for PCR kit (Clontech, Mountain View, CA). cDNA was amplified using quantitative real-time PCR with Assays-on-Demand premixed Taqman primer/probe set for mouse BACE1 mRNA (catalog \#Mm00478664_m1; Applied Biosystems, Foster City, CA) and analyzed using an Applied Biosystems 7900HT sequence analyzer with the relative quantification method normalized against 18S rRNA (Applied Biosystems catalog \#4333760F). Samples were run in triplicate, sample averages were determined, and then means and SEMs were calculated based on the sample averages. All procedures were performed according to the recommendations of the manufacturer.

Histology. Hemibrains were sectioned parasagittally on a freezing microtome at $30 \mu \mathrm{m}$. Alternate serial sections were floated in $0.1 \mathrm{M}$ phosphate buffer, $\mathrm{pH}$ 7.6, and then were either stained in cresyl violet or incubated with rabbit anti-glial fibrillary acidic protein (GFAP) primary antibody (1:10,000; Sigma) overnight at room temperature. After subsequent washes, the sections were incubated with secondary biotinylated goat anti-rabbit at 1:2000 for $2 \mathrm{~h}$ at room temperature. The Vector Laboratories (Burlingame, $\mathrm{CA}$ ) ABC kit was used with $\mathrm{DAB}$ as chromagen to visualize the reaction product. Sections were then mounted on charged slides, dehydrated in a series of alcohols, cleared in xylene, and coverslipped. Hematoxylin was used as a counterstain for GFAP immunohistochemistry. Differential interference contrast microscopy was performed using a Nikon (Tokyo, Japan) E800 microscope with a Spot advanced digital camera (Diagnostic Instruments, Sterling Heights, MI) for capturing images.

Statistical methods. Immunoblot and ELISA quantifications are presented as the mean \pm SEM. Comparisons between groups were made using one-way ANOVA and Prism (Graph Pad Software, San Diego, CA) with post hoc analysis by Neuman-Keuls test. An effect of treatment was defined as significant if $p<0.05$ by the $F$ test in the ANOVA. 


\section{Results}

Pharmacological inhibition of energy production in the brain To initially test the hypothesis that cerebral energy impairment may be proamyloidogenic, we examined whether transient reductions in energy production in vivo would increase BACE1 and A $\beta$ levels. To do so, we treated 2- to 3-month-old wild-type C57/B6 and transgenic Tg2576 mice by single intraperitoneal injection with several pharmacological agents that inhibit energy metabolism by different mechanisms: (1) insulin (18 U/kg), which induces rapid, severe hypoglycemia; (2) 2DG (1 g/kg), a competitive inhibitor of glucose that binds and reversibly inactivates hexokinase, thus reducing glucose flux through glycolysis; (3) $3 \mathrm{NP}$ (100 mg/kg), an irreversible inhibitor of succinate dehydrogenase, thus inhibiting carbon flux through the Krebs' cycle; (4) KA (30 mg/kg), a glutamate analog that induces seizure and evokes a large energy demand on glutaminergic neurons. These agents and doses have been shown in previous studies to induce acute reduction in brain energy production without causing significant neurodegeneration (Auer et al., 1984; McKhann et al., 2003; Brownell et al., 2004).

All treated mice displayed typical behaviors associated with inhibition of energy metabolism, including low or no motor activity, lethargy, and lack of response to touch. For insulininduced hypoglycemia, these behaviors correlated with extremely low blood glucose levels $(20-30 \mathrm{mg} / \mathrm{dl}$ in insulin-injected mice compared with $\sim 130 \mathrm{mg} / \mathrm{dl}$ in vehicle-injected mice). For KA-treated animals, reduced motor activity preceded the onset of mild-to-moderate seizures (stages 2-4) (McKhann et al., 2003). Behavioral onset was rapid after injections with 2DG, 3NP, and KA ( 5-10 $\mathrm{min})$ and more delayed for insulin treatment ( 45-60 min). All mice generally recovered within $4 \mathrm{~h}$, and no additional abnormal behaviors were observed for up to $7 \mathrm{~d}$ (the last time point analyzed).

To determine whether neurodegeneration occurred as a result of treatments, after $7 \mathrm{~d}$ of recovery, brains from representative treated mice were harvested, and alternate brain sections were stained with either cresyl violet or anti-GFAP antibody counterstained with hematoxylin. GFAP immunoreactivity was not elevated in brains from treated mice compared with vehicle controls (Fig. 1), indicating that the energy inhibitors did not induce significant astrogliosis, a well known response to trauma or stress in the brain (for review, see Little and O'Callaghan, 2001). Importantly, the treatments did not appear to cause obvious signs of neurodegeneration after examination of cresyl violet (data not shown) or hematoxylin-stained (Fig. 1) brain sections. Together, our observations indicated that treatment with all of the pharmacological agents led to acute reduction of energy metabolism in the brain without significant neurodegeneration or astrogliosis over the time period tested.

\section{Cerebral BACE1 levels are elevated after energy inhibition}

After administration of energy inhibitors, mice were allowed to recover for $4 \mathrm{~h}, 2 \mathrm{~d}$, or $7 \mathrm{~d}$. Brains were then harvested and bisected, and hemibrains were prepared for histology or SDSPAGE/immunoblot analysis and A $\beta 40$ ELISA. First, we investigated whether reduced energy metabolism in the brain would cause an increase in BACE1 levels, as determined by immunoblot analysis. It has been our experience that many anti-BACE1 antibodies label nonspecific bands on immunoblots, thus, to determine the specificity of the anti-BACE1 antibody (PA1-757; Affinity Bioreagents) used in this study, we performed immunoblot analysis of brain homogenates from BACE1 ${ }^{+/+}$and BACE1 ${ }^{-/-}$ control mice (Luo et al., 2001). PA1-757 recognizes the C termini

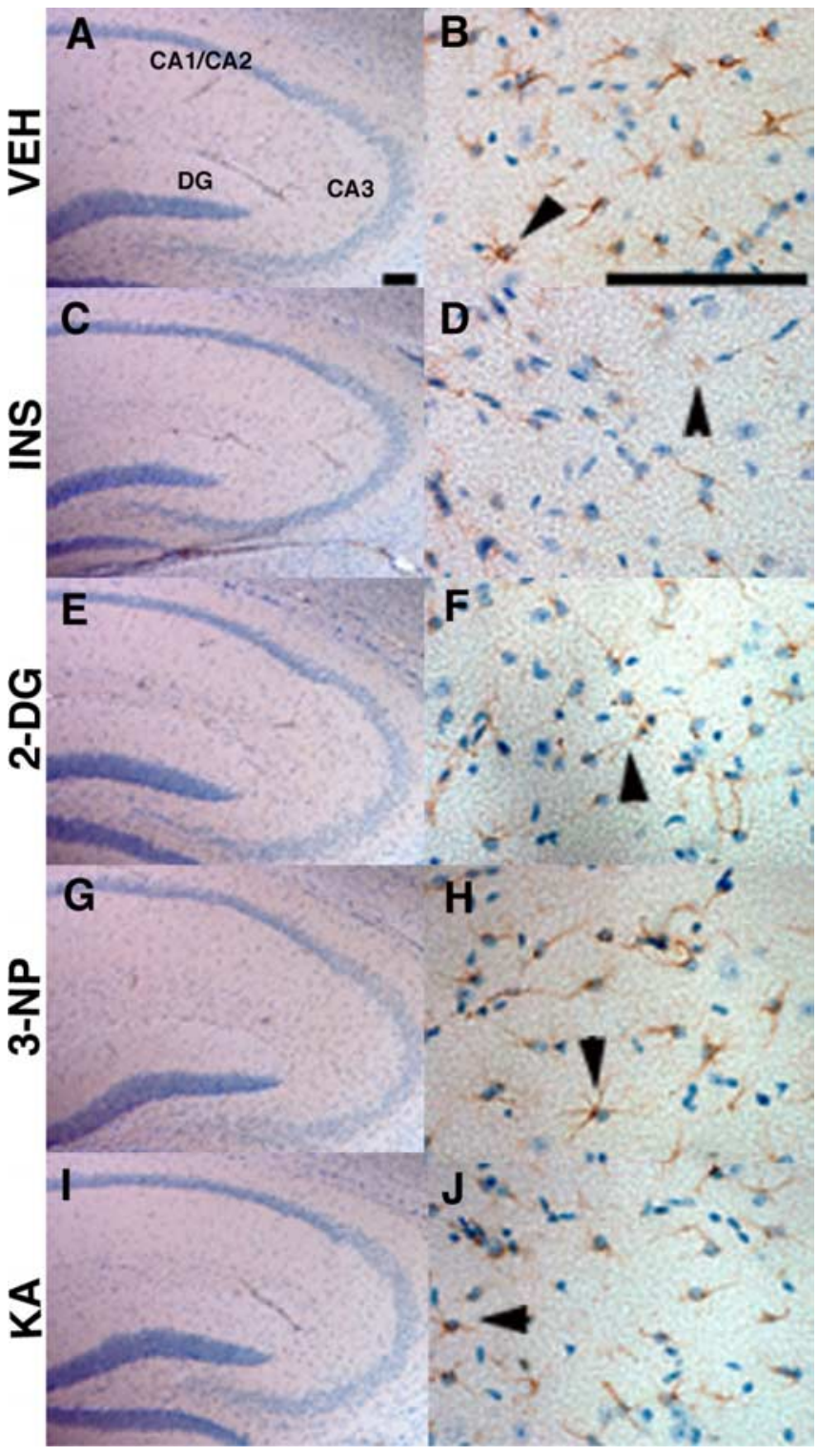

Figure 1. Acute energy inhibition does not cause overt neurodegeneration or astrogliosis. $\boldsymbol{A}-\boldsymbol{J}$, Two- to 3-month-old $\mathrm{Tg} 2576$ mice were given a single intraperitoneal injection of $18 \mathrm{U} / \mathrm{kg}$ insulin (INS; $\boldsymbol{C}, \boldsymbol{D}), 1 \mathrm{~g} / \mathrm{kg} 2 \mathrm{DG}(\boldsymbol{E}, \boldsymbol{F}), 100 \mathrm{mg} / \mathrm{kg} 3 \mathrm{NP}(\boldsymbol{G}, \boldsymbol{H}), 30 \mathrm{mg} / \mathrm{kg} \mathrm{KA}(\boldsymbol{I}, \boldsymbol{J})$, or vehicle (VEH; $\boldsymbol{A}, \boldsymbol{B})$ and were then allowed to recover for $7 \mathrm{~d}$. Brains were harvested, parasagittal sections were cut, and immunohistochemistry was performed using an anti-GFAP antibody and hematoxylin counterstaining. $\boldsymbol{A}, \boldsymbol{C}, \boldsymbol{E}, \boldsymbol{G}, \boldsymbol{I}$, Low-magnification images of the hippocampus showing pyramidal cell layers of $C A 1 / 2, C A 3$, and the dentate gyrus (DG). No significant reduction in cell-layer thickness was observed with any of the treatments compared with vehicle control, demonstrating that energy inhibitors did not cause gross neuronal loss or neurodegeneration. $\boldsymbol{B}, \boldsymbol{D}, \boldsymbol{F}, \boldsymbol{H}, \boldsymbol{J}$, High-magnification images of hippocampal astrocytes near CA3 stained with anti-GFAP antibody. Arrowheads show representative astrocytes. Note that comparable numbers of GFAPimmunopositive astrocytes are present in energy-inhibitor-treated and vehicle control hippocampi, indicating that agents did not induce significant astrogliosis. Scale bars: $A, B, 200 \mu \mathrm{m}$.

of both human and mouse BACE1 and identifies a band of $\sim 70$ $\mathrm{kDa}$ on immunoblots (Fig. 2). This $\sim 70 \mathrm{kDa}$ band was present in BACE $1^{+/+}$brain samples but was absent in the BACE1 ${ }^{-/-}$brain homogenate (Fig. 2, - lane). Moreover, lysate from a human BACE1-overexpressing 293 cell line showed a strong band at $\sim 70$ $\mathrm{kDa}$ (Fig. 2, + lane). Minor nonspecific bands of various sizes were also observed but could easily be distinguished from the BACE1 signal. Together, these results demonstrated that the PA1-757 anti-BACE1 antibody recognized authentic BACE1 in mouse brain homogenates by immunoblot. 


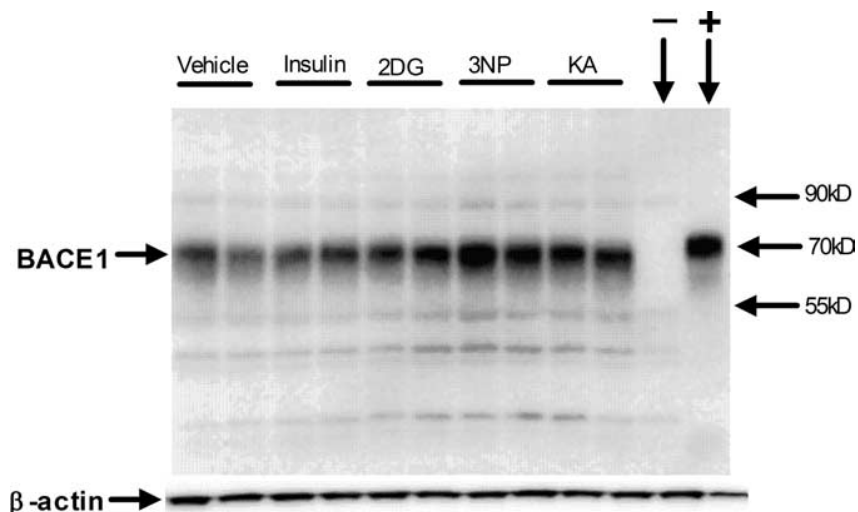

Figure 2. Representative BACE1 immunoblot of brain homogenates from treated Tg2576 mice. Two- to 3-month-old Tg2576 mice were given a single intraperitoneal injection of $18 \mathrm{U} / \mathrm{kg}$ insulin, $1 \mathrm{~g} / \mathrm{kg} 2 \mathrm{DG}, 100 \mathrm{mg} / \mathrm{kg} 3 \mathrm{NP}, 30 \mathrm{mg} / \mathrm{kg} \mathrm{KA}$, or vehicle and were then allowed to recover for $4 \mathrm{~h}$. Brains were harvested and homogenized, and $15 \mu \mathrm{g}$ of total protein per lane for each sample was separated on 10\% SDS-PAGE and transferred onto PVDF membrane. Blots were then incubated with anti-BACE1 antibody PA1-757 (directed against the C-terminal $17 \mathrm{aa}$ ), and signals were detected with $\mathrm{ECL}+$, followed by visualization on a Kodak imager (top panel). Blots were then stripped and reincubated with anti- $\beta$-actin antibody (bottom panel). Included on the blot was a BACE1 ${ }^{-1-}$ brain homogenate as a negative control ( - lane) and a lysate (1 $\mu \mathrm{g}$ ) from a human BACE1-overexpressing HEK293 (human embryonic kidney 293) cell line (+ lane). Molecular mass markers are indicated by arrows on the right. Note that the intensities of the BACE1 bands are significantly increased in brain samples from nearly all of the mice treated with energy inhibitors, compared with those that received vehicle only.

Having proven the specificity of the anti-BACE1 antibody, we then investigated the effects of acute energy inhibition on BACE1 levels in wild-type C57/B6 mouse brain homogenates by immunoblot. In vivo inhibition of energy production induced by each of the four pharmacological agents resulted in significant increases in BACE1 protein levels $(\sim 150 \%$ of vehicle control values) within $4 \mathrm{~h}$ [Fig. $3 A, B\left({ }^{* * *} p<0.001\right.$; one-way ANOVA)]. Moreover, BACE1 levels continued to be significantly elevated $(\sim 125-150 \%$ of vehicle control) after 2 and $7 \mathrm{~d}$ of recovery (Fig. $3 C-F)$. These results demonstrated that the increase in BACE1 protein levels is an early and long-lasting response to in vivo inhibition of energy production in the brains of wild-type C57/B6 mice.

To determine whether the BACE1 protein elevation was attributable to increased gene transcription or mRNA stability, we performed acute energy inhibition experiments on additional C57/B6 mice and measured BACE1 mRNA levels in the brain by quantitative real-time PCR (TaqMan; Applied Biosystems) analysis. Importantly, BACE1 mRNA levels did not appear to change significantly after any treatment or recovery period, compared with vehicle controls (data not shown), suggesting that BACE1 elevations after energy inhibition were unlikely to be the result of increased BACE1 gene expression or mRNA stability.

Tg2576 is a well studied transgenic mouse model of AD that overexpresses APP with the Swedish mutation (APPsw) (Mullan et al., 1992) and develops amyloid plaques at $\sim 9-12$ months of age (Hsiao et al., 1996). To determine the effects of acute energy inhibition on cerebral BACE1 levels and proamyloidogenic APP processing in vivo, we treated Tg2576 with single doses of the four energy inhibitors and allowed mice to recover for $4 \mathrm{~h}, 2 \mathrm{~d}$, and $7 \mathrm{~d}$, as before. At $4 \mathrm{~h}$ after injection, all treatments resulted in increases of brain BACE1 protein levels that were similar in magnitude to those observed in C57/B6 mice ( $~ 150 \%$ of vehicle control values; $p<0.001$, one-way ANOVA) (Figs. 2, 4A,B). As a control for the transgene, Tg2576 negative littermates were also treated and responded to all treatments in a manner similar to C57/B6 and Tg2576 positive mice (data not shown). When Tg2576 mice were allowed to recovery for 2 or $7 \mathrm{~d}$, BACE1 levels continued to be elevated to $\sim 130-145 \%$ and $\sim 127-140 \%$ of vehicle control values, respectively (Fig. $4 C-F$ ). Thus, BACE1 protein levels appeared to increase as a result of impaired brain energy metabolism regardless of mouse strain or the presence of the APP transgene, and levels remained elevated for at least 1 week after single-dose treatments.

Cerebral amyloidogenesis is increased after energy inhibition Because BACE1 is the key rate-limiting enzyme for $\mathrm{A} \beta$ production, we next determined whether acute cerebral energy inhibition would also increase the level of proamyloidogenic processing of APP in Tg2576 mice. The level of APPs $\beta$, the ectodomain produced after $\beta$-secretase cleavage of APP, reflects the amount of BACE1-induced processing of APP and parallels the level of A $\beta$ (Hussain et al., 1999; Sinha et al., 1999; Vassar et al., 1999; Yan et al., 1999; Lin et al., 2000). Therefore, we measured APPs $\beta$ levels in the brains of treated mice by immunoblot analysis using a neoepitope antibody that recognizes the cleaved $C$ terminus of APPs $\beta$ ending in the Swedish mutation $[\mathrm{APPs} \beta(\mathrm{sw})]$ but that reacts only weakly with full-length APP (Seubert et al., 1993; Vassar et al., 1999; Cole et al., 2005). We found that energy inhibition caused APPs $\beta$ (sw) levels to increase by as much as $\sim 175 \%$ compared with vehicle controls after 4 h of recovery (Fig. $5 A, B$ ), indicating that treatment-induced BACE1 elevation led to a rise in $\beta$-secretase cleavage of APP in vivo. APPs $\beta(\mathrm{sw})$ levels continued to be elevated for 2 and $7 \mathrm{~d}$ after treatments (Fig. $5 C-F$ ), again demonstrating a long-lasting effect. Immunoblot analysis with anti-APP antibodies did not reveal a significant increase in full-length APP levels after energy inhibition (data not shown), excluding the possibility that an increase in APPsw transgene expression was responsible for the elevated APPs $\beta(\mathrm{sw})$ levels.

To determine whether the apparent increase in $\beta$-secretase cleavage of APP resulted in elevated $\mathrm{A} \beta$ levels, we measured cerebral $A \beta 40$ in treated $\operatorname{Tg} 2576$ mice by $A \beta 40$-specific sandwich ELISA. After $4 \mathrm{~h}$ and $2 \mathrm{~d}$ of recovery, $\mathrm{A} \beta 40$ levels showed a trend toward elevation for several of the treatments, although significant differences were not found by ANOVA (Fig. 6A,B). However, by $7 \mathrm{~d}$ of recovery, Tg2576 brains had dramatically elevated A $\beta 40$ levels, rising to $\sim 200 \%$ of vehicle control values (Fig. $5 C$ ). Although we did not measure $A \beta 42$, production of both $A \beta 40$ and $A \beta 42$ change proportionally in parallel after alterations in BACE1 activity (Sinha et al., 1999; Vassar et al., 1999; Yan et al., 1999); thus, it is likely that $A \beta 42$ levels were also elevated in the brains of treated $\operatorname{Tg} 2576$ mice. Together, these results demonstrated that reduction of cerebral energy metabolism, although acute, produced a long-lasting elevation of both BACE1 and A $\beta$ levels in the brain.

\section{Discussion}

\section{Energy inhibition and amyloidogenic APP processing}

In this study, single acute pharmacological treatments that inhibited energy production caused prolonged elevations in cerebral levels of BACE1 in both wild-type and Tg2576 mice and in levels of $A P P s \beta$ and $A \beta 40$ in Tg2576. Importantly, we used compounds that inhibited energy production by different mechanisms, yet all showed similar effects, indicating that reduced energy metabolism was likely to underlie the elevation in BACE1 and $\mathrm{A} \beta$ levels. The agents did not induce visible neurodegeneration or astrogliosis at the doses used, although we cannot exclude the possibility of 
less obvious alterations, such as the release of subtoxic levels of reactive oxygen species (ROS) or inflammatory cytokines.

Although the BACE1 elevations were modest $(\sim 150 \%$ of control), they were long lasting (at least $7 \mathrm{~d}$ ). We do not yet know the maximum duration that BACE1 levels remain high after acute energy inhibition. As expected, increases in the levels of the product, $\mathrm{A} \beta 40$, temporally followed those of the enzyme, BACE1. Importantly, at $7 \mathrm{~d}$ after treatment, $A \beta 40$ levels reached $\sim 200 \%$ of control, thus exceeding the maximum percent increase for BACE1. Given the catalytic activity of BACE1, prolonged elevation of BACE1 levels could lead to large, cumulative increases of $\mathrm{A} \beta$ over time.

Recent reports have demonstrated that levels of BACE1 protein and activity are elevated in SAD (Fukumoto et al., 2002; Holsinger et al., 2002; Tyler et al., 2002; Yang et al., 2003; Li et al., 2004). In one study, $A \beta$ load positively correlated with BACE1 level in SAD brain (Li et al., 2004), suggesting that BACE1 elevation may drive $A \beta$ overproduction. Although these studies have clearly shown high BACE1 levels in SAD, they have not determined the underlying physiological processes that are involved in these effects. Here, our results strongly suggest that impaired cerebral energy production causes the BACE1 increase, which may, at least in part, be responsible for the $\mathrm{A} \beta$ elevation in SAD.

Unexpectedly, we observed a long lag period between the BACE1 and APPs $\beta$ elevation and the $A \beta 40$ increase. The temporal relationship between $\beta$ - and $\gamma$-secretase cleavage in neurons in vivo is not well understood, and we speculate that C99 intracellular trafficking to $\gamma$-secretase or the activity of $\gamma$-secretase may be limiting. Interestingly, recent work indicates that $\gamma$-secretase generation of $A \beta$ may be ATP dependent (Netzer et al., 2003). If so, lower ATP levels resulting from energy inhibition could temporarily decrease $\gamma$-secretase cleavage of C99 to cause a lag in $\mathrm{A} \beta$ formation. Future experiments should allow the determination of which, if any, of these hypotheses is correct.

Recently, we performed preliminary energy inhibition experiments with APPsw-overexpressing 293 cells in vitro and observed increased amyloidogenic processing (our unpublished results). Similar to the results of Gabuzda et al. (1994), energy inhibition caused an increase in the levels of intracellular amyloidogenic APP fragments. In addition, we observed an increase of secreted $A \beta$ levels during recovery from treatment. We did not determine whether $\mathrm{A} \beta$ levels were elevated intracellularly or extracellularly in our in vivo
A. $\mathrm{C} 57 / \mathrm{B} 6$ 4h recovery

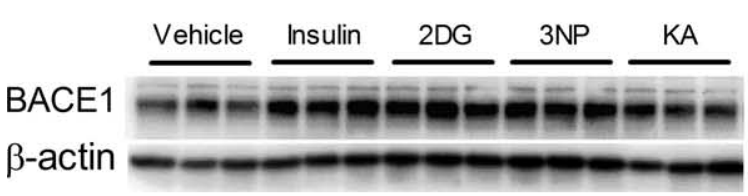

\section{C57/B6 2d recovery}

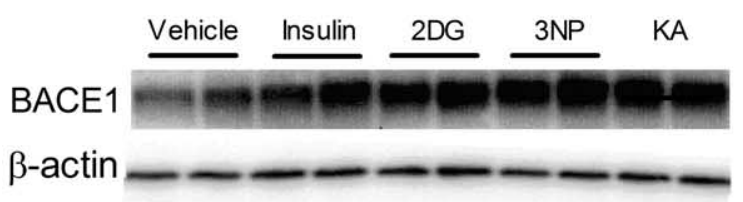

\section{E. C57/B6 7d recovery}

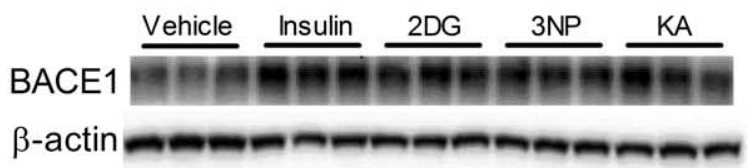

Figure 3. Acute energy inhibition increases BACE1 protein levels in the brains of $C 57 / B 6$ mice. $A-F$, Two- to 3 -month-old C57/B6 mice were given a single intraperitoneal injection of $18 \mathrm{U} / \mathrm{kg}$ insulin, $1 \mathrm{~g} / \mathrm{kg} 2 \mathrm{DG}, 100 \mathrm{mg} / \mathrm{kg} 3 \mathrm{NP}, 30 \mathrm{mg} / \mathrm{kg} \mathrm{KA}$, or vehicle and were then allowed to recover for $4 \mathrm{~h}(\boldsymbol{A}, \boldsymbol{B}), 2 \mathrm{~d}(\boldsymbol{C}, \boldsymbol{D})$ or $7 \mathrm{~d}(\boldsymbol{E}, \boldsymbol{F})$. Brains were then isolated and homogenized, and samples (15 $\mu \mathrm{g} /$ lane) were subjected to immunoblot analysis for BACE1 protein using anti-BACE1 antibody PA1-757. Blots were stripped and reprobed with anti- $\beta$-actin antibody as a loading control. $A, C, E$, Representative BACE1 (top panels) and $\beta$-actin (bottom panels) immunoblots for the various treatments and recovery times are shown. $\boldsymbol{B}, \mathbf{D}, \boldsymbol{F}$, The intensities of $B A C E 1$ band signals were quantified on a Phosphorlmager (Eastman Kodak), normalized against the $\beta$-actin immunosignals for each sample, and then expressed as percentages of the mean of the vehicle control for a given recovery time. Note that the energy-inhibitor treatments elevated cerebral BACE1 protein levels to $\sim 125-150 \%$ of vehicle control values for all recovery times $\left({ }^{*} p<0.05,{ }^{* *} p<0.01\right.$, and $^{* * *} p<0.001$, one-way ANOVA with Newman-Keuls multiple-comparison test). $\boldsymbol{A}-\boldsymbol{D}$, Data represent mean \pm SEM; $n=9$ mice/treatment $(\boldsymbol{A}, \boldsymbol{B}), n=5$ mice/treatment $(\boldsymbol{C}, \boldsymbol{D})$, and $n=4$ mice/treatment $(\boldsymbol{E}, \boldsymbol{F})$.

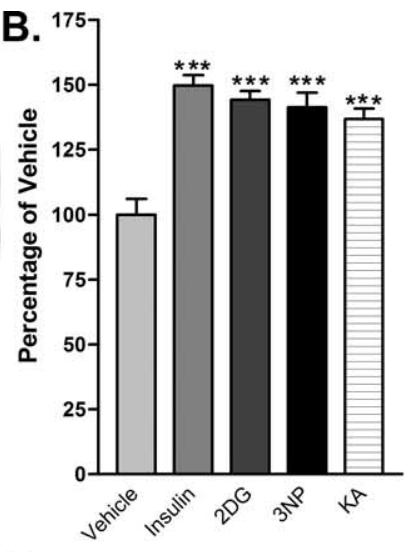

D.

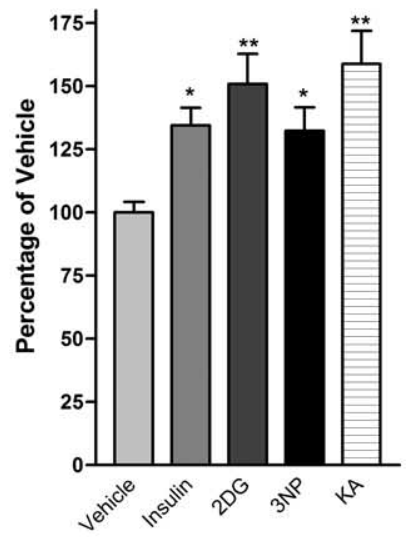

F.

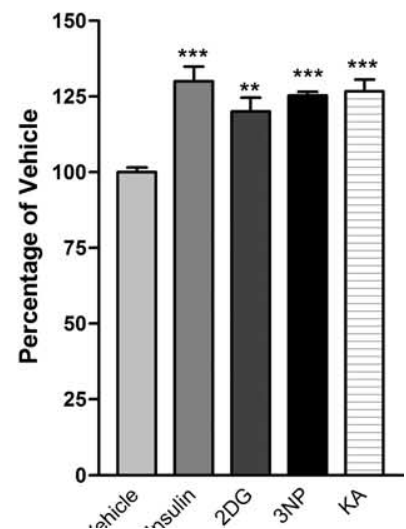


A. $\operatorname{Tg} 25764 \mathrm{~h}$ recovery

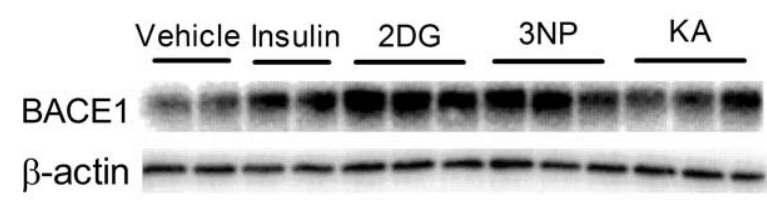

C. $\operatorname{Tg} 25762 \mathrm{~d}$ recovery

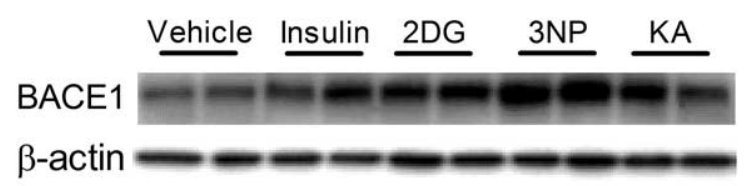

E. $\operatorname{Tg} 25767 d$ recovery

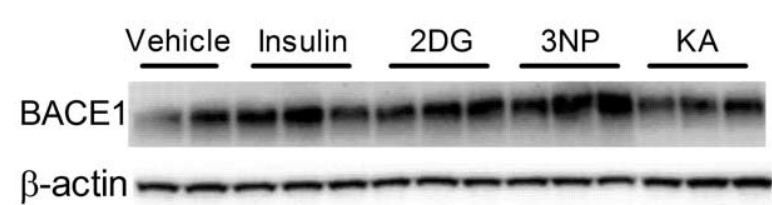

Figure 4. Acute energy inhibition increases BACE1 protein levels in the brains of Tg2576 mice. A-F, Two- to 3-month-old Tg2576 mice were injected with $18 \mathrm{U} / \mathrm{kg}$ insulin, $1 \mathrm{~g} / \mathrm{kg} 2 \mathrm{DG}, 100 \mathrm{mg} / \mathrm{kg} 3 \mathrm{NP}, 30 \mathrm{mg} / \mathrm{kg} \mathrm{KA}$, or vehicle and were allowed to recover for $4 \mathrm{~h}(\boldsymbol{A}, \boldsymbol{B}), 2 \mathrm{~d}(\boldsymbol{C}, \boldsymbol{D})$, or $7 \mathrm{~d}(\boldsymbol{E}, \boldsymbol{f}) . \boldsymbol{A}, \boldsymbol{C}, \boldsymbol{E}$, Representative immunoblots of brain samples for BACE1 (top panels) and $\beta$-actin (bottom panels). $\boldsymbol{B}, \boldsymbol{D}, \boldsymbol{F}, \mathrm{BACE1}$ immunosignals were quantified, normalized against $\beta$-actin signals, and expressed as percentages of vehicle controls, as before. Similar to the effects observed in C57/B6 mice, energy-inhibitor treatments in Tg2576 mice caused cerebral BACE1 levels to increase to $\sim 125-150 \%$ of vehicle controls for all recovery times $\left({ }^{*} p<0.05\right.$ and ${ }^{* *} p<0.01$, one-way ANOVA with Newman-Keuls multiple-comparison test). Data represent mean $\pm S E M ; n=6$ mice/treatment $(\boldsymbol{A}, \boldsymbol{B})$, and $n=4$ mice/treatment $(\boldsymbol{C}-\boldsymbol{F})$.

and recovery on the temporal and spatial characteristics of $\mathrm{A} \beta$ production in vivo.

The cell type in which the persistent BACE1 increase occurs is also an important unanswered question. The absence of significant treatment-induced astrogliosis argues against a rise in astrocytic BACE1, although the possibility exists that the level of BACE1 expression per astrocyte may increase without gliosis or GFAP elevation. We did not perform anti-BACE1 immunohistochemistry because, in our experience, anti-BACE1 antibodies produce nonspecific staining of BACE1 knock-out brain sections (R. Vassar and J. Zhao, unpublished results). In future studies, the availability of anti-BACE1 antibodies that provide specific staining in immunohistochemistry will allow unambiguous identification of the cell type(s) in which the BACE1 increase occurs.

We predict that energy inhibition should exacerbate both the amyloid deposition and behavioral impairment that occurs in Tg2576 mice (Hsiao et al., 1996). Plaques form after $\sim 9-12$ months in Tg2576; therefore, it is likely that periodic energy-inhibitor treatments spanning several months will be necessary to exacerbate amyloid deposition in this model. In addition, certain memory deficits in APP transgenic mice appear associated with soluble $\mathrm{A} \beta$ oligomers (Lambert et al., 1998; Hartley et al., 1999) rather than plaques (Holcomb et al., 1999; Dodart et al., 2002; Westerman et al., 2002; Ohno et al., 2004), and it will be important to investigate whether energy inhibition specifically elevates $\mathrm{A} \beta$ oligomers.

Although our work suggests that energy inhibition may increase $\mathrm{A} \beta$ production, at present, we cannot exclude the possibility that chronic energy insufficiency in SAD may decrease $\mathrm{A} \beta$ clearance or degradation, therefore allowing steadystate levels of $\mathrm{A} \beta$ to rise. It is conceivable that both the production and clearance limbs of the $A \beta$ economy balance may be altered in SAD so that cerebral $A \beta$ levels become elevated in an additive manner. Future studies aimed at examining $\mathrm{A} \beta$ turnover after energy-inhibitor treatments should determine the effects of energy failure on $\mathrm{A} \beta$ clearance.

Potential mechanisms underlying the persistent BACE1 increase

The mechanism of the energy-inhibitioninduced BACE1 increase is unclear and will be challenging to elucidate. However, we speculate that translational control may be involved because (1) we do not observe a significant BACE1 mRNA increase after treatment; (2) BACE1 protein halflife is too long (8-16 h) (Haniu et al., 2000; Huse et al., 2000) to account for the rapid rise in BACE1 levels; and (3) recent studies show that the $5^{\prime}$ untranslated region (5'UTR) of BACE1 mRNA influences translational efficiency (De Pietri Tonelli et al., 2004; Lammich et al., 2004; Rogers et al., 2004). BACE1 mRNA contains a long, GC-rich 5'UTR with three upstream open reading frames (uORFs) that is similar to $5^{\prime}$ UTRs that regulate the translation of certain growth factors, cytokines, hormone receptors, protein kinases, transcription factors, polyamine biosynthesis enzymes, and regulators of the cell cycle and apoptosis (for review, see Clemens and Bommer, 1999). Translational control via these $5^{\prime}$ UTRs is not well understood; however, it appears that the GC-rich sequence confers secondary structure that inhibits cap-dependent translation, and the uORFs reduce 
the translation of the downstream ORF. Moreover, translational inhibition may be relieved in a variety of circumstances, including growth and development, specific cells and tissues, and cellular stresses. These conditions activate a number of signaling pathways, including the MAPK (mitogen-activated protein kinase), PKC, PI3 (phosphoinositide 3), and p38 kinase cascades. Downstream consequences of signaling include the phosphorylation of the translation initiation factor eIF4E and its binding protein 4E-BP1, which increases the rate of cap-dependent translation. Other processes may also occur, such as increased unwinding activity of $5^{\prime} \mathrm{UTR}$ secondary structure and activation of RNA-binding proteins that overcome uORF inhibition. Although it has not yet been demonstrated that energy deficiency increases translational efficiency via structured, uORF-containing 5'UTRs, the stress-activated p38 pathway has been shown to control translation through these $5^{\prime}$ UTRs and is likely activated by energy metabolic stress. Therefore, we propose that energy insufficiency, perhaps through the p38 pathway, may elevate BACE1 mRNA translational efficiency via its 5'UTR. Clearly, much work remains to solve this important problem, but once it is fully understood, it may suggest novel therapeutic approaches for $\mathrm{AD}$.

One issue with the hypothesis that energy insufficiency causes SAD is the lack of association between cerebral infarcts and amyloid pathology (Schneider et al., 2004; Honig et al., 2005). The reason for this is unclear, although we speculate that infarcts may result in neuronal death before increased $\mathrm{A} \beta$ production can occur, or that the time between successive infarcts may be sufficient for clearance of excess $\mathrm{A} \beta$. Although macroscopic infarcts do not correlate with amyloidosis, recent studies have revealed an association between amyloid pathology and microinfarcts (Yip et al., 2005), some of which are found in brain regions that are prone to hypoperfusion (Suter et al., 2002). The correlation between amyloid, microinfarcts, and hypoperfusion is suggestive, because we favor the hypothesis that chronic hypoper-

fusion may establish long-term, sublethal energy insufficiency that causes sustained elevation of BACE1 and $A \beta$ levels. This chronic hypoperfusion may be the result of atherosclerosis, which appears to be greater in $\mathrm{AD}$ cerebrovasculature (Roher et al., 2003).

The hypoperfusion-induced molecular signals that trigger the BACE1 increase may be similar to those involved in ischemiareperfusion injury, including ROS and inflammatory cytokines. Recent reports that oxidative stress elevates BACE1 levels in cultured neurons (Tamagno et al., 2002, 2003) support a potential
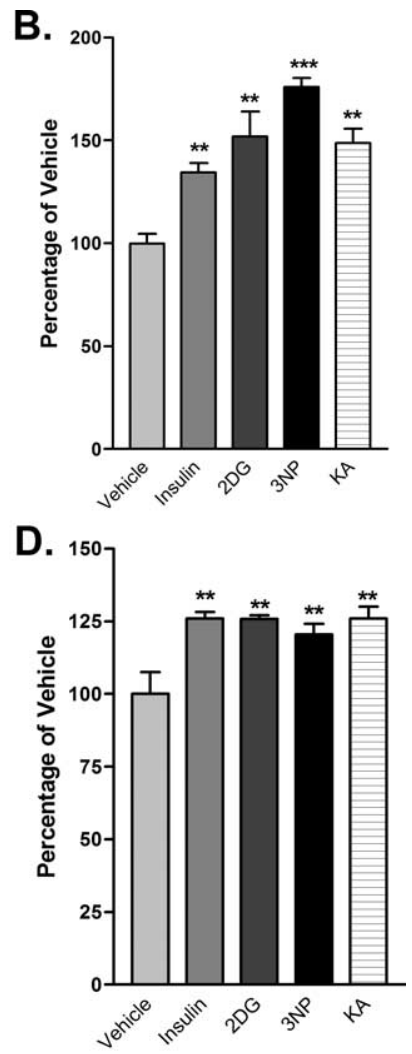

E. $\operatorname{Tg} 25767 d$ recovery
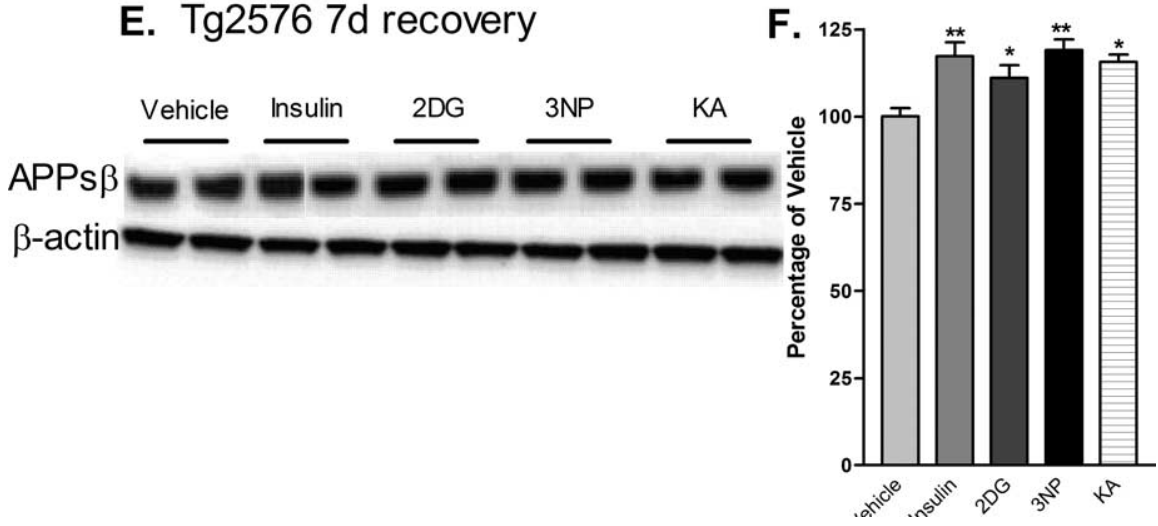

Figure 5. Cerebral levels of APPs $\beta(\mathrm{sw})$ are elevated after acute inhibition of energy production in Tg2576 mice. Brain homogenates from Tg2576 mice treated with $18 \mathrm{U} / \mathrm{kg}$ insulin, $1 \mathrm{~g} / \mathrm{kg} 2 \mathrm{DG}, 100 \mathrm{mg} / \mathrm{kg} 3 \mathrm{NP}, 30 \mathrm{mg} / \mathrm{kg} \mathrm{KA}$, or vehicle were subjected to immunoblot analysis using an antibody raised against the C-terminal neoepitope generated by BACE1 cleavage of APPsw, which recognizes APPs $\beta$ (sw) (Seubert et al., 1993; Vassar et al., 1999; Cole et al., 2005). $\boldsymbol{A}, \boldsymbol{C}, \boldsymbol{E}$, Representative APPs $\beta$ (sw) (top panels) and $\beta$-actin (bottom panels) immunoblots of brain samples from treated Tg2576 mice. Recovery times were for $4 \mathrm{~h}(\boldsymbol{A}, \boldsymbol{B}), 2 \mathrm{~d}(\boldsymbol{C}$ $\boldsymbol{D})$ or $7 \mathrm{~d}(\boldsymbol{E}, \boldsymbol{F}), \boldsymbol{B}, \boldsymbol{D}, \boldsymbol{F}, \mathrm{APPs} \beta(\mathrm{sw})$ immunosignals were normalized against $\beta$-actin signals and expressed as percentages of vehicle controls. Note that cerebral APPs $\beta($ sw) levels were increased to $\sim 125-175 \%$ of vehicle controls after $4 \mathrm{~h}$ of recovery from energy inhibition $(\boldsymbol{B})$, and they continued to be significantly elevated after $2 \mathrm{~d}(\boldsymbol{D})$ and $7 \mathrm{~d}(\boldsymbol{F})$ of recovery $\left({ }^{*} p<0.05,{ }^{* *} p<0.01\right.$, and ${ }^{* * *} p<0,001$, one-way ANOVA with Newman-Keuls multiple-comparison test). Data represent mean \pm SEM; $n=6$ mice/treatment $(\boldsymbol{A}, \boldsymbol{B})$, and $n=4$ mice/treatment $(\boldsymbol{C}-\boldsymbol{F})$.

role for ROS in the BACE1 increase in SAD. Similar mechanisms are likely to operate in diseases of other tissues, such as renal failure, in which chronic hypoperfusion of the kidney as a result of atherosclerosis appears to play a critical role, and oxidative stress and inflammation are important factors in progression (for review, see Textor, 2004). Testing the effects of models of hypoperfusion versus ischemia on BACE1 and A $\beta$ levels in APP transgenic mice would allow evaluation of the respective roles of oxidative stress and inflammation in the persistent BACE1 increase.

AD brains show decreased cerebral blood flow (Barclay et al., 


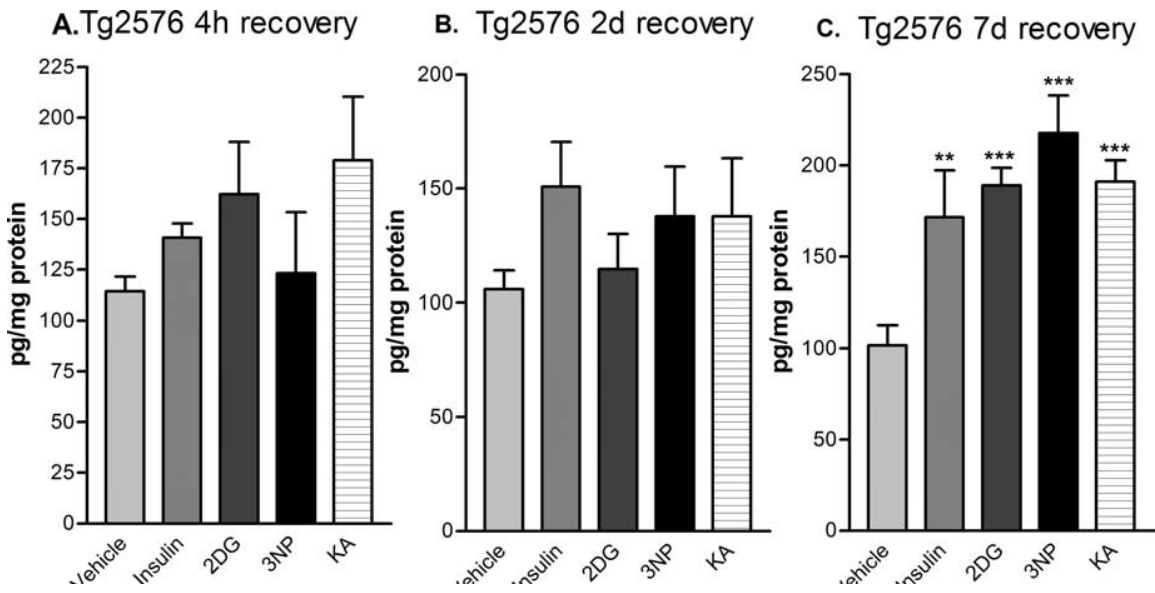

Figure 6. Acute energy inhibition increases cerebral A $\beta 40$ levels in Tg2576 mice. Brain homogenates from Tg2576 mice treated with $18 \mathrm{U} / \mathrm{kg}$ insulin, $1 \mathrm{~g} / \mathrm{kg} 2 \mathrm{DG}, 100 \mathrm{mg} / \mathrm{kg} \mathrm{3NP,} 30 \mathrm{mg} / \mathrm{kg} \mathrm{KA}$, or vehicle were subjected to A $\beta 40$-specific sandwich ELISA. Recovery times were for $4 \mathrm{~h}(\boldsymbol{A}), 2 \mathrm{~d}(\boldsymbol{B})$, or $7 \mathrm{~d}(\boldsymbol{C})$. $A \beta 40$ levels were expressed as picograms per milligram of total brain protein (determined by $B C A$ assay). Note that brain $A \beta 40$ levels showed a trend toward elevation for several of the treatments after $4 \mathrm{~h}$ and $2 \mathrm{~d}$ of recovery but did not reach significance. However, by $7 \mathrm{~d}$ of recovery, brain $A \beta 40$ levels were increased approximately twofold by all treatments. Data represent mean \pm SEM $\left({ }^{* *} p<0.01\right.$ and ${ }^{* * *} p<0.001$, one-way ANOVA with Newman-Keuls multiple-comparison test; $n=4$ per treatment).

1984; de la Torre, 1999; Matsuda, 2001; Matsuda et al., 2002), and glucose metabolism is reduced in both preclinical and clinical AD (de Leon et al., 1983a,b; Cutler et al., 1985; Rapoport et al., 1991; Meier-Ruge et al., 1994; Reiman et al., 1996; Rapoport, 1999; Small et al., 2000; De Santis et al., 2001; Ibach et al., 2004; Mosconi et al., 2004; Mosconi, 2005), suggesting that impaired energy metabolism may be an early pathological event in SAD. Moreover, cardiovascular diseases appear to increase the risk of AD (Breteler, 2000; Shi et al., 2000; de la Torre, 2004) and the incidence of cerebrovascular atherosclerosis is higher in AD (Roher et al., 2003; Kalback et al., 2004). Thus, cerebral blood flow and the delivery of glucose and oxygen to the brain may become progressively impaired during aging in some individuals to cause BACE1 elevation, $\mathrm{A} \beta$ overproduction, and SAD pathogenesis. Reduced clearance and/or degradation of $A \beta$ may also contribute to amyloid load in SAD.

\section{Physiological role of BACE1 elevation}

The physiological role of BACE1 elevation after energy inhibition is not yet known, but we speculate that it may involve a response to injury or stress. Indeed, BACE1 levels increase after noxious stimuli, including oxidative stress (Tamagno et al., 2002, 2003; Tong et al., 2005), TBI (Blasko et al., 2004), ischemia (Wen et al., 2004), and AD (Fukumoto et al., 2002; Holsinger et al., 2002; Tyler et al., 2002; Yang et al., 2003; Li et al., 2004). Now, we add energy inhibition to the growing list of stressors that induce BACE1. We speculate that stress/injury-induced BACE1 elevation facilitates recovery after acute stress/injury and that cleavage of BACE1 substrates is necessary for this function. However, chronic stress/injury results in pathologic BACE1 levels and amyloid formation.

BACE1 substrates thus far identified include APP, APP-like proteins (APLPs) 1 and 2 (Eggert et al., 2004; Li and Sudhof, 2004; Pastorino et al., 2004), P-selectin glycoprotein ligand-1 (PSGL-1) (Lichtenthaler et al., 2003), $\alpha 2,6$-sialyltransferase (ST6Gal I) (Kitazume et al., 2001, 2003, 2005), voltage-gated sodium channel $\beta$-subunit (Wong et al., 2005), and low-density lipoprotein receptor-related protein (LRP) (von Arnim et al., 2005). Interestingly, evidence suggests that these BACE1 substrates may be in- volved in the responses to stress and/or injury, such as recovery from excitotoxicity (A $\beta$ ) (Kamenetz et al., 2003), A $\beta$ clearance (LRP) (Hyman et al., 2000), synapse formation (APP, APLP1, and APLP2) (Herms et al., 2004; Wang et al., 2005), neuroprotection (secreted APP ectodomain) (Panegyres, 2001), and immune functions (PSGL-1 and ST6Gal I) (Kitazume et al., 2001; Lichtenthaler et al., 2003). It is essential to investigate the role of BACE1 elevation and substrate cleavage, because these processes likely affect the balance between health and disease.

Together, this evidence suggests that elevated BACE1 substrate processing may be beneficial during recovery after acute stresses/injuries. However, chronic stress/ injury could cause long-term BACE1 elevation and have harmful effects attributable to cerebral $A \beta$ overproduction. This is suggested by our observation that BACE1 and $\mathrm{A} \beta$ levels remain elevated for at least 1 week after a single episode of energy inhibition. If cerebral $A \beta 42$ production overwhelms clearance/degradation mechanisms, $A \beta 42$ levels will increase and likely trigger $\mathrm{SAD}$, just as it does in FAD. Finally, knowledge of the molecular mechanisms of BACE1 elevation during SAD may facilitate the development of novel therapeutic strategies to prevent or treat this devastating neurodegenerative disorder.

\section{References}

Auer RN, Wieloch T, Olsson Y, Siesjo BK (1984) The distribution of hypoglycemic brain damage. Acta Neuropathol (Berl) 64:177-191.

Barclay L, Zemcov A, Blass JP, McDowell FH (1984) Rapid rate of decline in cerebral blood flow in progressive dementias. Monogr Neural Sci 11:107-110.

Blasko I, Beer R, Bigl M, Apelt J, Franz G, Rudzki D, Ransmayr G, Kampfl A, Schliebs R (2004) Experimental traumatic brain injury in rats stimulates the expression, production and activity of Alzheimer's disease betasecretase (BACE-1). J Neural Transm 111:523-536.

Breteler MM (2000) Vascular risk factors for Alzheimer's disease: an epidemiologic perspective. Neurobiol Aging 21:153-160.

Brownell AL, Chen YI, Yu M, Wang X, Dedeoglu A, Cicchetti F, Jenkins BG, Beal MF (2004) 3-Nitropropionic acid-induced neurotoxicity-assessed by ultra high resolution positron emission tomography with comparison to magnetic resonance spectroscopy. J Neurochem 89:1206-1214.

Citron M, Oltersdorf T, Haass C, McConlogue L, Hung AY, Seubert P, VigoPelfrey C, Lieberburg I, Selkoe DJ (1992) Mutation of the beta-amyloid precursor protein in familial Alzheimer's disease increases beta-protein production. Nature 360:672-674.

Clemens MJ, Bommer UA (1999) Translational control: the cancer connection. Int J Biochem Cell Biol 31:1-23.

Cole SL, Grudzien A, Manhart IO, Kelly BL, Oakley H, Vassar R (2005) Statins cause intracellular accumulation of APP, beta-secretase cleaved fragments, and Abeta via an isoprenoid-dependent mechanism. J Biol Chem 280:18755-18770.

Cutler NR, Haxby JV, Duara R, Grady CL, Moore AM, Parisi JE, White J, Heston L, Margolin RM, Rapoport SI (1985) Brain metabolism as measured with positron emission tomography: serial assessment in a patient with familial Alzheimer's disease. Neurology 35:1556-1561.

de la Torre JC (1999) Critical threshold cerebral hypoperfusion causes Alzheimer's disease? Acta Neuropathol (Berl) 98:1-8.

de la Torre JC (2004) Is Alzheimer's disease a neurodegenerative or a vascular disorder? Data, dogma, and dialectics. Lancet Neurol 3:184-190.

de Leon MJ, Ferris SH, George AE, Reisberg B, Christman DR, Kricheff II, Wolf AP (1983a) Computed tomography and positron emission trans- 
axial tomography evaluations of normal aging and Alzheimer's disease. J Cereb Blood Flow Metab 3:391-394.

de Leon MJ, Ferris SH, George AE, Christman DR, Fowler JS, Gentes C, Reisberg B, Gee B, Emmerich M, Yonekura Y, Brodie J, Kricheff II, Wolf AP (1983b) Positron emission tomographic studies of aging and Alzheimer disease. AJNR Am J Neuroradiol 4:568-571.

De Pietri Tonelli D, Mihailovich M, Di Cesare A, Codazzi F, Grohovaz F, Zacchetti D (2004) Translational regulation of BACE-1 expression in neuronal and non-neuronal cells. Nucleic Acids Res 32:1808-1817.

De Santis S, de Leon MJ, Rusinek H, Convit A, Tarshish CY, Roche A, Tsui WH, Kandil E, Boppana M, Daisley K, Wang GJ, Schlyer D, Fowler J (2001) Hippocampal formation glucose metabolism and volume losses in MCI and AD. Neurobiol Aging 22:529-539.

Dodart JC, Bales KR, Gannon KS, Greene SJ, DeMattos RB, Mathis C, DeLong CA, Wu S, Wu X, Holtzman DM, Paul SM (2002) Immunization reverses memory deficits without reducing brain Abeta burden in Alzheimer's disease model. Nat Neurosci 5:452-457.

Eggert S, Paliga K, Soba P, Evin G, Masters CL, Weidemann A, Beyreuther K (2004) The proteolytic processing of the amyloid precursor protein gene family members APLP- 1 and APLP- 2 involves alpha-, beta-, gamma-, and epsilon-like cleavages: modulation of APLP-1 processing by n-glycosylation. J Biol Chem 279:18146-18156.

Esler WP, Wolfe MS (2001) A portrait of Alzheimer secretases-new features and familiar faces. Science 293:1449-1454.

Fukumoto H, Cheung BS, Hyman BT, Irizarry MC (2002) Beta-secretase protein and activity are increased in the neocortex in Alzheimer disease. Arch Neurol 59:1381-1389.

Gabuzda D, Busciglio J, Chen LB, Matsudaira P, Yankner BA (1994) Inhibition of energy metabolism alters the processing of amyloid precursor protein and induces a potentially amyloidogenic derivative. J Biol Chem 269:13623-13628.

Gasparini L, Racchi M, Benussi L, Curti D, Binetti G, Bianchetti A, Trabucchi M, Govoni S (1997) Effect of energy shortage and oxidative stress on amyloid precursor protein metabolism in COS cells. Neurosci Lett 231:113-117.

Gasparini L, Benussi L, Bianchetti A, Binetti G, Curti D, Govoni S, Moraschi S, Racchi M, Trabucchi M (1999) Energy metabolism inhibition impairs amyloid precursor protein secretion from Alzheimer's fibroblasts. Neurosci Lett 263:197-200.

Glenner GG, Wong CW (1984) Alzheimer's disease: initial report of the purification and characterization of a novel cerebrovascular amyloid protein. Biochem Biophys Res Commun 120:885-890.

Haniu M, Denis P, Young Y, Mendiaz EA, Fuller J, Hui JO, Bennett BD, Kahn S, Ross S, Burgess T, Katta V, Rogers G, Vassar R, Citron M (2000) Characterization of Alzheimer's beta-secretase protein BACE. A pepsin family member with unusual properties. J Biol Chem 275:21099-21106.

Hardy J, Selkoe DJ (2002) The amyloid hypothesis of Alzheimer's disease: progress and problems on the road to therapeutics. Science 297:353-356.

Hartley DM, Walsh DM, Ye CP, Diehl T, Vasquez S, Vassilev PM, Teplow DB, Selkoe DJ (1999) Protofibrillar intermediates of amyloid beta-protein induce acute electrophysiological changes and progressive neurotoxicity in cortical neurons. J Neurosci 19:8876-8884.

Herms J, Anliker B, Heber S, Ring S, Fuhrmann M, Kretzschmar H, Sisodia S, Muller U (2004) Cortical dysplasia resembling human type 2 lissencephaly in mice lacking all three APP family members. EMBO J 23:4106-4115.

Holcomb LA, Gordon MN, Jantzen P, Hsiao K, Duff K, Morgan D (1999) Behavioral changes in transgenic mice expressing both amyloid precursor protein and presenilin-1 mutations: lack of association with amyloid deposits. Behav Genet 29:177-185.

Holsinger RM, McLean CA, Beyreuther K, Masters CL, Evin G (2002) Increased expression of the amyloid precursor beta-secretase in Alzheimer's disease. Ann Neurol 51:783-786.

Honig LS, Kukull W, Mayeux R (2005) Atherosclerosis and AD: analysis of data from the US National Alzheimer's Coordinating Center. Neurol 64:494-500.

Hsiao K, Chapman P, Nilsen S, Eckman C, Harigaya Y, Younkin S, Yang F, Cole G (1996) Correlative memory deficits, Abeta elevation, and amyloid plaques in transgenic mice. Science 274:99-102.

Huse JT, Pijak DS, Leslie GJ, Lee VM, Doms RW (2000) Maturation and endosomal targeting of beta-site amyloid precursor protein-cleaving en- zyme. The Alzheimer's disease beta-secretase. J Biol Chem 275:33729-33737.

Hussain I, Powell D, Howlett DR, Tew DG, Meek TD, Chapman C, Gloger IS, Murphy KE, Southan CD, Ryan DM, Smith TS, Simmons DL, Walsh FS, Dingwall C, Christie G (1999) Identification of a novel aspartic protease (Asp 2) as beta-secretase. Mol Cell Neurosci 14:419-427.

Hyman BT, Strickland D, Rebeck GW (2000) Role of the low-density lipoprotein receptor-related protein in beta-amyloid metabolism and Alzheimer disease. Arch Neurol 57:646-650.

Ibach B, Poljansky S, Marienhagen J, Sommer M, Manner P, Hajak G (2004) Contrasting metabolic impairment in frontotemporal degeneration and early onset Alzheimer's disease. NeuroImage 23:739-743.

Kalback W, Esh C, Castano EM, Rahman A, Kokjohn T, Luehrs DC, Sue L, Cisneros R, Gerber F, Richardson C, Bohrmann B, Walker DG, Beach TG, Roher AE (2004) Atherosclerosis, vascular amyloidosis and brain hypoperfusion in the pathogenesis of sporadic Alzheimer's disease. Neurol Res 26:525-539.

Kamenetz F, Tomita T, Hsieh H, Seabrook G, Borchelt D, Iwatsubo T, Sisodia S, Malinow R (2003) APP processing and synaptic function. Neuron 37:925-937.

Kitazume S, Tachida Y, Oka R, Shirotani K, Saido TC, Hashimoto Y (2001) Alzheimer's beta-secretase, beta-site amyloid precursor protein-cleaving enzyme, is responsible for cleavage secretion of a Golgi-resident sialyltransferase. Proc Natl Acad Sci USA 98:13554-13559.

Kitazume S, Tachida Y, Oka R, Kotani N, Ogawa K, Suzuki M, Dohmae N, Takio K, Saido TC, Hashimoto Y (2003) Characterization of alpha 2,6sialyltransferase cleavage by Alzheimer's beta-secretase (BACE1). J Biol Chem 278:14865-14871.

Kitazume S, Nakagawa K, Oka R, Tachida Y, Ogawa K, Luo Y, Citron M, Shitara H, Taya C, Yonekawa H, Paulson JC, Miyoshi E, Taniguchi N, Hashimoto Y (2005) In vivo cleavage of alpha2,6-sialyltransferase by Alzheimer beta-secretase. J Biol Chem 280:8589-8595.

Lambert MP, Barlow AK, Chromy BA, Edwards C, Freed R, Liosatos M, Morgan TE, Rozovsky I, Trommer B, Viola KL, Wals P, Zhang C, Finch CE, Krafft GA, Klein WL (1998) Diffusible, nonfibrillar ligands derived from $A \beta 1-42$ are potent central nervous system neurotoxins. Proc Natl Acad Sci USA 95:6448-6453.

Lammich S, Schobel S, Zimmer AK, Lichtenthaler SF, Haass C (2004) Expression of the Alzheimer protease BACE1 is suppressed via its $5^{\prime}$ untranslated region. EMBO Rep 5:620-625.

Li Q, Sudhof TC (2004) Cleavage of amyloid-beta precursor protein and amyloid-beta precursor-like protein by BACE 1 . J Biol Chem 279:10542-10550.

Li R, Lindholm K, Yang LB, Yue X, Citron M, Yan R, Beach T, Sue L, Sabbagh M, Cai H, Wong P, Price D, Shen Y (2004) Amyloid beta peptide load is correlated with increased beta-secretase activity in sporadic Alzheimer's disease patients. Proc Natl Acad Sci USA 101:3632-3637.

Lichtenthaler SF, Dominguez DI, Westmeyer GG, Reiss K, Haass C, Saftig P, De Strooper B, Seed B (2003) The cell adhesion protein P-selectin glycoprotein ligand-1 is a substrate for the aspartyl protease BACE1. J Biol Chem 278:48713-48719.

Lin X, Koelsch G, Wu S, Downs D, Dashti A, Tang J (2000) Human aspartic protease memapsin 2 cleaves the beta-secretase site of beta-amyloid precursor protein. Proc Natl Acad Sci USA 97:1456-1460.

Little AR, O'Callaghan JP (2001) Astrogliosis in the adult and developing CNS: is there a role for proinflammatory cytokines? Neurotoxicology 22:607-618.

Luo Y, Bolon B, Kahn S, Bennett BD, Babu-Khan S, Denis P, Fan W, Kha H, Zhang J, Gong Y, Martin L, Louis JC, Yan Q, Richards WG, Citron M, Vassar R (2001) Mice deficient in BACE1, the Alzheimer's betasecretase, have normal phenotype and abolished beta-amyloid generation. Nat Neurosci 4:231-232.

Masters CL, Simms G, Weinman NA, Multhaup G, McDonald BL, Beyreuther K (1985) Amyloid plaque core protein in Alzheimer disease and Down syndrome. Proc Natl Acad Sci USA 82:4245-4249.

Matsuda H (2001) Cerebral blood flow and metabolic abnormalities in Alzheimer's disease. Ann Nucl Med 15:85-92.

Matsuda H, Kanetaka H, Ohnishi T, Asada T, Imabayashi E, Nakano S, Katoh A, Tanaka F (2002) Brain SPET abnormalities in Alzheimer's disease before and after atrophy correction. Eur J Nucl Med Mol Imaging 29:1502-1505.

McKhann GM, Wenzel HJ, Robbins CA, Sosunov AA, Schwartzkroin PA 
(2003) Mouse strain differences in kainic acid sensitivity, seizure behavior, mortality, and hippocampal pathology. Neuroscience 122:551-561.

Meier-Ruge W, Bertoni-Freddari C, Iwangoff P (1994) Changes in brain glucose metabolism as a key to the pathogenesis of Alzheimer's disease. Gerontology 40:246-252.

Mosconi L (2005) Brain glucose metabolism in the early and specific diagnosis of Alzheimer's disease FDG-PET studies in MCI and AD. Eur J Nucl Med Mol Imaging 32:486-510.

Mosconi L, Perani D, Sorbi S, Herholz K, Nacmias B, Holthoff V, Salmon E, Baron JC, De Cristofaro MT, Padovani A, Borroni B, Franceschi M, Bracco L, Pupi A (2004) MCI conversion to dementia and the APOE genotype: a prediction study with FDG-PET. Neurology 63:2332-2340.

Mullan M, Crawford F, Axelman K, Houlden H, Lilius L, Winblad B, Lannfelt L (1992) A pathogenic mutation for probable Alzheimer's disease in the APP gene at the N-terminus of beta-amyloid. Nat Genet 1:345-347.

Netzer WJ, Dou F, Cai D, Veach D, Jean S, Li Y, Bornmann WG, Clarkson B, $\mathrm{Xu} \mathrm{H}$, Greengard P (2003) Gleevec inhibits beta-amyloid production but not Notch cleavage. Proc Natl Acad Sci USA 100:12444-12449.

Ohno M, Sametsky EA, Younkin LH, Oakley H, Younkin SG, Citron M, Vassar R, Disterhoft JF (2004) BACE1 deficiency rescues memory deficits and cholinergic dysfunction in the Tg2576 mouse model of Alzheimer's disease. Neuron 41:27-33.

Panegyres PK (2001) The functions of the amyloid precursor protein gene. Rev Neurosci 12:1-39.

Pastorino L, Ikin AF, Lamprianou S, Vacaresse N, Revelli JP, Platt K, Paganetti P, Mathews PM, Harroch S, Buxbaum JD (2004) BACE (beta-secretase) modulates the processing of APLP2 in vivo. Mol Cell Neurosci 25:642-649.

Rapoport SI (1999) In vivo PET imaging and postmortem studies suggest potentially reversible and irreversible stages of brain metabolic failure in Alzheimer's disease. Eur Arch Psychiatry Clin Neurosci 249 [Suppl 3]:46-55.

Rapoport SI, Horwitz B, Grady CL, Haxby JV, DeCarli C, Schapiro MB (1991) Abnormal brain glucose metabolism in Alzheimer's disease, as measured by position emission tomography. Adv Exp Med Biol 291:231-248

Reiman EM, Caselli RJ, Yun LS, Chen K, Bandy D, Minoshima S, Thibodeau SN, Osborne D (1996) Preclinical evidence of Alzheimer's disease in persons homozygous for the epsilon 4 allele for apolipoprotein E. N Engl J Med 334:752-758.

Rogers Jr GW, Edelman GM, Mauro VP (2004) Differential utilization of upstream AUGs in the beta-secretase mRNA suggests that a shunting mechanism regulates translation. Proc Natl Acad Sci USA 101:2794-2799.

Roher AE, Esh C, Kokjohn TA, Kalback W, Luehrs DC, Seward JD, Sue LI, Beach TG (2003) Circle of willis atherosclerosis is a risk factor for sporadic Alzheimer's disease. Arterioscler Thromb Vasc Biol 23:2055-2062.

Schneider JA, Wilson RS, Bienias JL, Evans DA, Bennett DA (2004) Cerebral infarctions and the likelihood of dementia from Alzheimer disease pathology. Neurology 62:1148-1155.

Seubert P, Oltersdorf T, Lee MG, Barbour R, Blomquist C, Davis DL, Bryant K, Fritz LC, Galasko D, Thal LJ (1993) Secretion of beta-amyloid precursor protein cleaved at the amino terminus of the beta-amyloid peptide. Nature 361:260-263.

Shi J, Perry G, Smith MA, Friedland RP (2000) Vascular abnormalities: the insidious pathogenesis of Alzheimer's disease. Neurobiol Aging 21:357-361.

Sinha S, Anderson JP, Barbour R, Basi GS, Caccavello R, Davis D, Doan M, Dovey HF, Frigon N, Hong J, Jacobson-Croak K, Jewett N, Keim P, Knops J, Lieberburg I, Power M, Tan H, Tatsuno G, Tung J, Schenk D, et al. (1999) Purification and cloning of amyloid precursor protein betasecretase from human brain. Nature 402:537-540.

Sisodia SS, Kim SH, Thinakaran G (1999) Function and dysfunction of the presenilins. Am J Hum Genet 65:7-12.

Small GW, Ercoli LM, Silverman DH, Huang SC, Komo S, Bookheimer SY, Lavretsky H, Miller K, Siddarth P, Rasgon NL, Mazziotta JC, Saxena S, Wu
HM, Mega MS, Cummings JL, Saunders AM, Pericak-Vance MA, Roses AD, Barrio JR, Phelps ME (2000) Cerebral metabolic and cognitive decline in persons at genetic risk for Alzheimer's disease. Proc Natl Acad Sci USA 97:6037-6042.

Suter O-C, Sunthorn T, Kraftsik R, Straubel J, Darekar P, Khalili K, Miklossy J (2002) Cerebral hypoperfusion generates cortical watershed microinfarcts in Alzheimer disease. Stroke 33:1986-1992.

Tamagno E, Bardini P, Obbili A, Vitali A, Borghi R, Zaccheo D, Pronzato MA, Danni O, Smith MA, Perry G, Tabaton M (2002) Oxidative stress increases expression and activity of BACE in NT2 neurons. Neurobiol Dis 10:279-288.

Tamagno E, Guglielmotto M, Bardini P, Santoro G, Davit A, Di Simone D, Danni O, Tabaton M (2003) Dehydroepiandrosterone reduces expression and activity of BACE in NT2 neurons exposed to oxidative stress. Neurobiol Dis 14:291-301.

Textor S (2004) Ischemic nephropathy: where are we now? J Am Soc Nephrol 15:1974-1982.

Tong Y, Zhou W, Fung V, Christensen MA, Qing H, Sun X, Song W (2005) Oxidative stress potentiates BACE1 gene expression and Abeta generation. J Neural Transm 112:455-469.

Tyler SJ, Dawbarn D, Wilcock GK, Allen SJ (2002) Alpha- and beta-secretase: profound changes in Alzheimer's disease. Biochem Biophys Res Commun 299:373-376.

Vassar R, Bennett BD, Babu-Khan S, Kahn S, Mendiaz EA, Denis P, Teplow DB, Ross S, Amarante P, Loeloff R, Luo Y, Fisher S, Fuller J, Edenson S, Lile J, Jarosinski MA, Biere AL, Curran E, Burgess T, Louis JC, et al. (1999) Beta-secretase cleavage of Alzheimer's amyloid precursor protein by the transmembrane aspartic protease BACE. Science 286:735-741.

von Arnim CA, Kinoshita A, Peltan ID, Tangredi MM, Herl L, Lee BM, Spoelgen R, Hshieh TT, Ranganathan S, Battey FD, Liu CX, Bacskai BJ, Sever S, Irizarry MC, Strickland DK, Hyman BT (2005) The LDLreceptor related protein (LRP) is a novel beta-secretase (BACE 1) substrate. J Biol Chem 280:17777-17785.

Wang P, Yang G, Mosier DR, Chang P, Zaidi T, Gong YD, Zhao NM, Dominguez B, Lee KF, Gan WB, Zheng H (2005) Defective neuromuscular synapses in mice lacking amyloid precursor protein (APP) and APPlike protein 2. J Neurosci 25:1219-1225.

Webster MT, Pearce BR, Bowen DM, Francis PT (1998) The effects of perturbed energy metabolism on the processing of amyloid precursor protein in PC12 cells. J Neural Transm 105:839-853.

Wen Y, Onyewuchi O, Yang S, Liu R, Simpkins JW (2004) Increased betasecretase activity and expression in rats following transient cerebral ischemia. Brain Res 1009:1-8.

Westerman MA, Cooper-Blacketer D, Mariash A, Kotilinek L, Kawarabayashi T, Younkin LH, Carlson GA, Younkin SG, Ashe KH (2002) The relationship between Abeta and memory in the Tg2576 mouse model of Alzheimer's disease. J Neurosci 22:1858-1867.

Wong HK, Sakurai T, Oyama F, Kaneko K, Wada K, Miyazaki H, Kurosawa M, De Strooper B, Saftig P, Nukina N (2005) Beta subunits of voltagegated sodium channels are novel substrates of BACE1 and gammasecretase. J Biol Chem 280:23009-23017.

Yan R, Bienkowski MJ, Shuck ME, Miao H, Tory MC, Pauley AM, Brashier JR, Stratman NC, Mathews WR, Buhl AE, Carter DB, Tomasselli AG, Parodi LA, Heinrikson RL, Gurney ME (1999) Membrane-anchored aspartyl protease with Alzheimer's disease beta-secretase activity. Nature 402:533-537.

Yang LB, Lindholm K, Yan R, Citron M, Xia W, Yang XL, Beach T, Sue L, Wong P, Price D, Li R, Shen Y (2003) Elevated beta-secretase expression and enzymatic activity detected in sporadic Alzheimer disease. Nat Med 9:3-4.

Yip AG, McKee AC, Green RC, Wells J, Young H, Cupples LA, Farrer LA (2005) APOE, vascular pathology, and the AD brain. Neurol 65:259-265.

Younkin SG (1998) The role of A beta 42 in Alzheimer's disease. J Physiol (Paris) 92:289-292. 